\title{
Contraception in mice immunized with recombinant zona pellucida subunit 3 proteins correlates with Th2 responses and the levels of interleukin 4 expressed by $\mathrm{CD}^{+}$cells
}

\author{
Gavin Clydesdale, Jenny Pekin, Sandra Beaton, Ronald J Jackson, Soma Vignarajan and \\ Christopher M Hardy \\ Pest Animal Control Cooperative Research Centre, CSIRO Sustainable Ecosystems, GPO Box 284, Canberra, \\ Australian Capital Territory 2601, Australia
}

Correspondence should be addressed to C Hardy; Email: chris.hardy@csiro.au

\begin{abstract}
The immune responses and contraceptive effect in mice were tested following immunization with purified recombinant zona pellucida (ZP) proteins produced using a vaccinia (v) virus T7 mammalian expression system. Female BALB/c and CBA mice were immunized with recombinant mouse (m) ZP3 (vmZP3) or pig (p) ZPC (vpZPC) using Freund's adjuvants and boosted three times. Fertility and mean litter size were significantly reduced in groups of BALB/c mice immunized with recombinant vmZP3 and vpZPC compared with controls treated with Freund's adjuvants alone. In CBA mice, fertility and mean litter size were significantly reduced in groups of animals immunized with vmZP3 but not with vpZPC compared with the controls. Most infertile animals treated with vmZP3 and a single infertile BALB/c mouse treated with vpZPC lacked mature follicles in the ovaries, whilst no abnormalities were detected in the remaining vpZPC treated, fertile vmZP3 treated and control mice. All mice (both fertile and infertile) immunized with vmZP3 and vpZPC produced IgG antibodies, but the levels of total IgG, IgG1 and IgG2a did not correlate with infertility. All BALB/c and CBA mice immunized with vmZP3 and vpZPC showed greater delayed type hypersensitivity responses in the footpads after challenge with their respective antigens than controls, but these did not differ between the fertile and infertile mice. There was, however, a significant correlation between infertility and the levels of the Type $2 \mathrm{~T}$ helper cell (Th2) cytokine interleukin 4 produced by $\mathrm{CD}^{+}$cells from vmZP3 immunized mice in response to stimulation with vmZP3 and this did not apply to the levels of the Type 1 T helper cell (Th1) cytokine interferon gamma or the general proliferation response. The results support the conclusion that induction of Th2 responses in individual mice determines whether infertility develops in response to immunization with zona pellucida proteins.

Reproduction (2004) 128 737-745
\end{abstract}

\section{Introduction}

A critical requirement for immunocontraceptive vaccines is that they be highly effective. Partially effective vaccines are unlikely to be acceptable to the regulatory authorities that govern product releases. Replicating viral vaccines expressing zona pellucida (ZP) antigens are able to deliver highly effective fertility control to mice (Jackson et al. 1998, Chambers et al. 1999, Lloyd et al. 2003) and rabbits (Kerr et al. 1999). However, substantive issues relating to the long-term safety of such replicating vaccines, public acceptance and regulatory approval remain to be resolved before this system can be deployed. A far more attractive option in the shorter term is to explore whether alternative vaccines that are non-replicating and which can be delivered using currently approved procedures such as injection or oral delivery (Zhang et al. 1997, Miller et al. 1999a) can be made as effective as replicating vaccines.

The simplest form of non-replicating fertility control vaccines use complex mixtures of naturally produced proteins prepared from sources such as pig ovaries (Sacco et al. 1981, Mahi-Brown et al. 1985, Kirkpatrick et al. 1992, Brown et al. 1997, Miller et al. 1999b, Li et al. 2002). They are expensive, time consuming to prepare and obviously not suited to large scale applications and markets. Quality control, sourcing of crude material and inadvertent spread of diseases are major problems potentially associated with the use of native proteins. A more attractive option is to use recombinant proteins to ensure greater scalability and quality control.

Prototype ZP-based subunit vaccines have been tested in many different forms for in vivo infertility effects. Materials tested have included purified native proteins 
(Sacco et al. 1987, 1989, Dunbar et al. 1989, Hasegawa et al. 1992), DNA vaccines (Ramsay \& Ramshaw 1997), chemically produced peptide vaccines (Millar et al. 1989, Rhim et al. 1992, Lou et al. 1995a, Sadler et al. 1999, Hardy et al. 2002b) and recombinant proteins purified from a variety of different protein expression systems, including bacterial (Schwoebel et al. 1992, VandeVoort et al. 1995, Govind \& Gupta 2000, Hardy et al. 2002a, Lea et al. 2002, Srivastava et al. 2002), insect (Prasad et al. 1996), plant (Fitchen et al. 1995) and mammalian cells (Kerr et al. 1999, Martinez \& Harris 2000). However, such subunit vaccines for fertility control have been highly variable in their effectiveness and have yet to be developed to the point where their use can be justified. Since not all animals vaccinated with recombinant ZP proteins are rendered infertile, we are exploring the critical immunological responses required for effective contraception in the mouse model.

In this paper we compare the relative immunocontraceptive effects of immunizing mice with purified homologous mouse $(\mathrm{m}) \mathrm{ZP} 3$ and heterologous pig (p) ZPC (ZP3ß) recombinant proteins produced using a vaccinia $(v)$ virus expression system in mammalian cells. The data indicate that more than one mechanism can lead to infertility in mice and support the hypothesis that Type $2 \mathrm{~T}$ helper cell (Th2) responses play a role in the development of autoimmune infertility in response to immunization with zona pellucida proteins.

\section{Materials and Methods}

\section{Expression and purification of recombinant $m Z P 3$ and pZPC proteins}

Myxoma virus expressing mouse ZP3 (mmZP3) and vaccinia virus expressing mouse ZP3 (vmZP3) have been described previously (Jackson et al. 1998, Hardy et al. 2003). Vaccinia virus expressing pig ZPC (vpZPC) was produced using plasmid pTM1-pZPC and a vaccinia virus/T7 RNA polymerase hybrid expression system (Wyatt et al. 1995) as described (Hardy et al. 2003). Plasmid pTM1-pZPC was prepared by inserting a $1.3 \mathrm{~kb}$ Ncol/EcoRI DNA fragment of pZPC (GenBank Accession Number L22169) from plasmid pZ057 (a gift from Dr Jeff Harris, Zonagen, The Woodlands, TX, USA) between the $\mathrm{Ncol} /$ EcoRI sites of pTM1.

Recombinant vmZP3 and vpZPC proteins were produced in CV-1 African Green Monkey (Ceropithecus aethiops) kidney fibroblast cells (ATCC CCL-70) and recombinant mmZP3 was produced in RK13 rabbit cells (ATCC CCL-37) as previously described (Jackson et al. 1998, Hardy et al. 2003). All proteins were affinity purified over a Wheat Germ Lectin Sepharose 6B column (Amersham International, Amersham, Bucks, UK) and recombinant vmZP3 was further purified over a Ni-NTA Superflow (Qiagen) column as previously described (Hardy et al. 2003). The recombinant proteins appeared as diffuse protein bands on SDS-polyacrylamide gels with apparent molecular masses principally around $56 \mathrm{kDa}$ for mmZP3 and vmZP3 and $51 \mathrm{kDa}$ for vpZPC (results not shown).

\section{Mouse strains}

BALB/c mice (6 to 8 weeks old) were obtained from the Animal Resources Centre (Murdoch, Perth, Western Australia, Australia). CBA mice (6 to 8 weeks old) were obtained from the Australian National University Animal Facility (Canberra, ACT, Australia).

\section{Immunization and mating protocols}

The Animal Experimentation and Ethics Committee of CSIRO Sustainable Ecosystems approved all animal experimental procedures, in compliance with the Australian National Health and Medical Research Council guidelines. Female mice (6 to 8 weeks old) were injected intraperitoneally with $20 \mu \mathrm{g}$ antigen or PBS in $100 \mu \mathrm{l} 50 \%$ $(\mathrm{v} / \mathrm{v})$ Freund's Complete Adjuvant (Sigma, St Louis, MO, USA). The animals were then boosted 3 times with $20 \mu \mathrm{g}$ antigen or PBS in $100 \mu \mathrm{l} 50 \%(\mathrm{v} / \mathrm{v})$ Freund's Incomplete Adjuvant at 2-week intervals. In addition, mice received a further injection with vmZP3 or vpZPC antigen in $50 \mu \mathrm{l}$ PBS without adjuvants into each hind footpad ( $5 \mu \mathrm{g} /$ footpad) 2 weeks after the final immunization, to measure the delayed type hypersensitivity (DTH) response. Mice were bled from the suborbital vein of the orbital sinus immediately prior to the first injection and again 2 weeks after the final boost. The blood was then spun at 1500 r.p.m. for $5 \mathrm{~min}$ and the sera collected and stored at $-20^{\circ} \mathrm{C}$ until needed.

All mice were coupled (one male for each female) one day after the footpad immunization with single proven fertile males of similar age. Males were removed after 2 weeks (four oestrus cycles) and the females allowed to litter. Fertility of males was then confirmed by mating with untreated females. Female mice mated with males subsequently found to be infertile were removed from the trial (3 BALB/c treated with vpZPC, 3 BALB/C treated with $\mathrm{PBS}$, and $1 \mathrm{CBA}$ mouse treated with $\mathrm{PBS}$ ). A further 2 mice treated with vmZP3 died during the immunizations. The number of pups produced by each female was then counted.

\section{Measurement of delayed type hypersensitivity response}

Mice were weighed prior to challenge and anaesthetised by intraperitoneal injection using a $1 \mathrm{ml}$ syringe and a 25 -gauge needle with $10 \mu \mathrm{l}$ Nembutal $(6 \mathrm{mg}$ sodium pentobarbitol $/ \mathrm{ml}$ in $80 \%$ distilled water, $10 \%$ ethanol and $10 \%$ propylene glycol) per gram of body weight minus $10 \%$. Following anaesthesia, the thicknesses of the hind footpads were measured using a spring-loaded micrometer, then $50 \mu \mathrm{l}$ of appropriate antigen were injected into each hind footpad and the swelling response of the hind footpads was measured after $24 \mathrm{~h}$. 


\section{Assay of antibodies}

Serum IgG antibody levels against recombinant antigens were determined by enzyme-linked immunosorbent assay (ELISA) in 96-well plates (Nunclon Surface Tissue culture plates, Nalge Nunc, Rochester, NY, USA) using mmZP3 as the detection antigen to avoid cross-reaction to vaccinia virus proteins as previously described (Hardy et al. 2003). Secondary antibodies were horseradish peroxidase (HRP)conjugated affinity purified goat anti-mouse IgG (Bio-Rad Laboratories, Hercules, CA, USA) or HRP-conjugated rabbit anti-mouse IgG1 and HRP-conjugated rabbit antimouse IgG2a (Zymed, S. San Francisco, CA, USA).

\section{Histology and immunofluorescence}

Mice were killed and the ovaries were collected, fixed in Bouin's solution $(71.4 \%$ saturated picric acid, 9.5\% formaldehyde, $4.8 \%$ glacial acetic acid) and embedded in paraffin wax. Sections $(7 \mu \mathrm{m})$ were stained with haematoxylin and eosin.

\section{Proliferation assay}

Spleens were harvested from euthanised mice and single cell suspensions were prepared. Spleen cell suspensions from fertile and infertile mice of the same strain were pooled separately. $\mathrm{CD}^{+}$cells were isolated from the cell suspensions using anti-mouse CD4-coated Dynabeads and detached from the beads by the DETACHaBead system (Dynal Biotech, Oslo, Norway). The isolated $\mathrm{CD}^{+}$cells were washed three times then added to a 96-well microtitre plate and doubling dilutions were performed. The cells were stimulated in the presence of mitomycin C-treated accessory cells (spleen cells from naïve animals) in the presence or absence of vmZP3 $(5 \mu \mathrm{g} / \mathrm{ml})$ at $37^{\circ} \mathrm{C}$ under $5 \%$ $\mathrm{CO}_{2}$. The in vitro antigen recall response of lymphocytes to vmZP3 was measured by $18 \mathrm{~h}\left[{ }^{3} \mathrm{H}\right.$-]thymidine incorporation at day 5 of culture. Cells were harvested onto filter paper and radioactivity measured using a TopCount scintillation counter (Perkin Elmer, Freemont, CA, USA).

\section{Cytokine assays}

In parallel with the proliferation assay, and using the same accessory cells, CD4 ${ }^{+} \mathrm{T}$ cells were cultured for $24 \mathrm{~h}$ and the supernatants were harvested. A capture ELISA was used (ELISA Mouse OptEIA IL-4 and IFN $\gamma$ Set, BD Biosciences Pharmingen, San Diego, CA, USA) to measure interleukin (IL)-4 and interferon (IFN)- $\gamma$ according to protocols recommended by the manufacturer. Standard curves were established to quantify the levels of the respective cytokines in the supernatants.

\section{Statistical analysis}

Results are presented as means \pm S.E.M. Data were analysed by two-way analysis of variance (ANOVA) and multiple comparisons between groups were conducted using the Tukey-Kramer Multiple Comparison Test (Number Cruncher Statistical System, NCSS, Kaysville, UT, USA). Immunological data resulting from the proliferation assay and cytokine ELISAs were analysed using two-tailed Student's $t$-tests. A value of $P<0.05$ was accepted as significant.

\section{Results}

\section{Effects of immunization with vmZP3 and vpZPC on fertility}

The effects of immunization with vmZP3 and vpZPC proteins on fertility and associated immune responses in $\mathrm{BALB} / \mathrm{C}$ and CBA mice were assessed. The fertility rate of BALB/c mice fell from $93 \%$ in the phosphate buffered saline (PBS) controls to $56 \%$ and $64 \%$ in vmZP3 and vpZPC immunized mice respectively (Table 1). In CBA mice fertility was reduced from $100 \%$ in PBS controls to $40 \%$ and $71 \%$ in vmZP3 and vpZPC immunized mice respectively. In BALB/c mice, the mean litter sizes were significantly different between those immunized with vmZP3 and vpZPC compared with those immunized with PBS. In CBA mice, the mean litter size of the group immunized with vmZP3, but not vpZPC, was significantly different to PBS immunized controls. We attribute the observed

Table 1 Fertility of female BALB/C and CBA mice immunized with recombinant zona pellucida proteins. Values are means \pm S.E.M.

\begin{tabular}{|c|c|c|c|c|c|c|c|c|c|}
\hline \multirow[b]{2}{*}{ Mouse strain } & \multirow[b]{2}{*}{ Antigen } & \multirow[b]{2}{*}{ Total mice } & \multirow[b]{2}{*}{ Fertile mice } & \multirow[b]{2}{*}{$\%$ Fertile } & \multirow[b]{2}{*}{ Total pups } & \multicolumn{2}{|c|}{$\begin{array}{l}\text { Mean litter size } \\
\quad \text { (all mice) }\end{array}$} & \multicolumn{2}{|c|}{$\begin{array}{l}\text { Mean litter size } \\
\text { (fertile mice) }\end{array}$} \\
\hline & & & & & & $n$ & $P$ & $n$ & $P$ \\
\hline \multirow[t]{3}{*}{$\mathrm{BALB} / \mathrm{c}$} & vmZP3 & 18 & 10 & 56 & 47 & $2.6 \pm 0.6$ & 0.003 & $4.7 \pm 0.3$ & $N / S$ \\
\hline & vpZPC & 14 & 9 & 64 & 36 & $2.6 \pm 0.7$ & 0.006 & $4.0 \pm 0.6$ & \\
\hline & PBS & 28 & 26 & 93 & 136 & $4.9 \pm 0.5$ & & $5.2 \pm 0.3$ & \\
\hline \multirow[t]{3}{*}{ CBA } & vmZP3 & 15 & 6 & 40 & 32 & $2.1 \pm 0.7$ & 0.004 & $5.3 \pm 0.8$ & $\mathrm{~N} / \mathrm{S}$ \\
\hline & vpZPC & 7 & 5 & 71 & 30 & $4.3 \pm 1.0$ & $\mathrm{~N} / \mathrm{S}$ & $6.0 \pm 0.9$ & $\mathrm{~N} / \mathrm{S}$ \\
\hline & PBS & 12 & 12 & 100 & 66 & $5.5 \pm 0.7$ & & $5.5 \pm 0.8$ & \\
\hline
\end{tabular}

Female mice were immunized intraperitoneally with antigen in Freund's Complete Adjuvant, boosted 3 times with the same antigen at twoweek intervals in Freund's Incomplete Adjuvant, and mated two weeks after the final boost. PBS, phosphate buffered saline; vmZP3, mouse ZP3 produced in a vaccinia virus expression system; vpZPC, pig ZPC produced in a vaccinia virus expression system. $P$ values were obtained using a General Linear Model ANOVA and indicate where a significant difference $(P<0.05)$ was present between treated and control groups. N/S, not significant. 
effects on fertility in the groups to a reduction in the number of animals that produced litters rather than to a reduction in litter size, since there was no significant difference between the mean litter sizes of the fertile BALB/c or CBA mice treated with vmZP3, vpZPC and PBS (Table 1).

\section{Delayed type hypersensitivity}

The DTH responses of mice to vmZP3 and vpZPC were tested to determine if the level of cellular immune responses and Type $1 \mathrm{~T}$ helper cell (Th1) type immunity correlated with infertility. All mice immunized with vmZP3 and vpZPC produced significantly higher DTH responses $(P<0.0001)$ to the respective proteins than the PBS immunized controls (Table 2). However, there were no significant differences in the magnitude of the DTH responses between infertile and fertile mice of either strain. The DTH response of CBA mice to vpZPC was, however, significantly higher than the responses in all other groups $(P<0.001)$.

\section{Cellular immune responses to immunization with vmZP3}

The vmZP3 antigen was selected for use in a more detailed in vitro study; vpZPC was not tested since it was not successful in reducing litter size in CBA mice. The in vitro proliferation responses of $\mathrm{CD}^{+}$cells to vmZP3, assessed by thymidine uptake, did not differ between infertile and fertile mice of either strain. Control values are from purified $\mathrm{CD}^{+}$cells from naïve mice stimulated with or without vmZP3 (Table 3). The levels of IL-4 in culture supernatants were significantly higher in infertile animals of both strains, and the effect was most pronounced in CBA mice. However, values were lower than those from naïve mice stimulated with vmZP3 (Table 3 ). The IFN $\gamma$ response to vmZP3 was more complex and straindependent differences were observed relative to the IFN $\gamma$ levels in supernatants from naïve $\mathrm{CD}^{+}{ }^{+}$stimulated with vmZP3. Supernatants from infertile BALB/c mice contained less IFN $\gamma$ than those from fertile BALB/C mice, whereas supernatants from fertile CBA mice contained higher IFN $\gamma$ levels than those from infertile mice (Table 3).

\section{Humoral immune responses to immunization with vmZP3}

The relationship between antibody responses and induction of infertility in BALB/C and CBA mice after immunization with vmZP3 and vpZPC was investigated. All

Table 2 DTH response in female BALB/C and CBA mice immunized with zona pellucida proteins.

\begin{tabular}{|c|c|c|c|c|c|c|}
\hline Mouse strain & Immunization antigen & DTH antigen & Infertile mice & $\begin{array}{c}\text { DTH response }^{a} \\
(\text { mean } \pm \text { S.E.M. })\end{array}$ & Fertile mice & $\begin{array}{r}\text { DTH response }{ }^{\mathrm{a}} \\
(\text { mean } \pm \text { S.E.M. })\end{array}$ \\
\hline \multirow[t]{3}{*}{$\mathrm{BALB} / \mathrm{C}$} & vmZP3 & vmZP3 & 8 & $11.8 \pm 1.1$ & 10 & $10.7 \pm 0.5$ \\
\hline & vpZPC & vpZPC & 5 & $9.2 \pm 0.6$ & 9 & $9.5 \pm 1.1$ \\
\hline & PBS & vmZP3/vpZPC & 2 & $1.3 \pm 1.3$ & 26 & $1.0 \pm 0.2$ \\
\hline \multirow[t]{3}{*}{ CBA } & vmZP3 & vmZP3 & 9 & $10.6 \pm 0.5$ & 6 & $9.2 \pm 0.6$ \\
\hline & vpZPC & vpZPC & 2 & $16.3 \pm 0.8$ & 5 & $15.2 \pm 1.7$ \\
\hline & PBS & vmZP3/vpZPC & 0 & N/A & 12 & $1.7 \pm 0.4$ \\
\hline
\end{tabular}

${ }^{a}$ Delayed type hypersensitivity (DTH) response is the mean swelling $(\mathrm{mm})$ per footpad from the average of two hind footpads each injected with $5 \mu \mathrm{g}$ protein antigen in PBS. PBS, phosphate buffered saline; vmZP3, mouse ZP3 produced in a vaccinia virus expression system; vpZPC, pig ZPC produced in a vaccinia virus expression system. All groups of animals immunized with vmZP3 and vpZPC had significantly higher DTH responses than PBS control animals $(P \ll 0.0001)$ using a General Linear Model ANOVA. CBA mice immunized with vpZPC showed significantly higher DTH responses $(P<0.001)$ than all the other groups. There was no significant difference in DTH responses within mouse strains between fertile and infertile animals. N/A, not applicable.

Table 3 The proliferation response and cytokine expression of spleen cells from BALB/c and CBA mice immunized vmZP3. Values are means \pm S.E.M.

\begin{tabular}{|c|c|c|c|c|c|c|c|c|c|}
\hline Strain & Number of mice & Stimulation & Status & Thymidine uptake (cpm) & $\boldsymbol{P}^{a}$ & IFN $\boldsymbol{\gamma}(\mathrm{pg} / \mathrm{ml})$ & $P^{a}$ & IL-4 (pg/ml) & $\boldsymbol{P}^{a}$ \\
\hline \multirow[t]{4}{*}{$\mathrm{BALB} / \mathrm{C}$} & 5 & vmZP3 & Infertile & $4691 \pm 768$ & \multirow[t]{4}{*}{$\mathrm{N} / \mathrm{S}$} & $847 \pm 26$ & \multirow[t]{4}{*}{$<0.0001$} & $71 \pm 1$ & \multirow[t]{4}{*}{0.0096} \\
\hline & 4 & vmZP3 & Fertile & $3192 \pm 68$ & & $1269 \pm 11$ & & $56 \pm 1$ & \\
\hline & 3 & vmZP3 & $N^{1 i ̈ v e}{ }^{b}$ & $1890 \pm 257$ & & $1138 \pm 40$ & & $254 \pm 7$ & \\
\hline & 3 & $\mathrm{Nil}$ & Naïve ${ }^{b}$ & $1825 \pm 279$ & & $\mathrm{~N} / \mathrm{T}$ & & $\mathrm{N} / \mathrm{T}$ & \\
\hline \multirow[t]{4}{*}{ CBA } & 5 & vmZP3 & Infertile & $5795 \pm 318$ & \multirow[t]{4}{*}{$\mathrm{N} / \mathrm{S}$} & $1273 \pm 46$ & \multirow[t]{4}{*}{0.0038} & $62 \pm 3$ & \multirow[t]{4}{*}{$<0.0001$} \\
\hline & 5 & vmZP3 & Fertile & $5569 \pm 153$ & & $990 \pm 6$ & & $3.7 \pm 0$ & \\
\hline & 3 & vmZP3 & Naïve & $3687 \pm 442$ & & $1169 \pm 53$ & & $126 \pm 7$ & \\
\hline & 3 & $\mathrm{Nil}$ & Naïve ${ }^{b}$ & $2333 \pm 46$ & & $\mathrm{~N} / \mathrm{T}$ & & $\mathrm{N} / \mathrm{T}$ & \\
\hline
\end{tabular}

Spleen cells recovered from fertile and infertile female BALB/c and CBA mice immunized with vmZP3 were enriched for CD4 ${ }^{+}$cells $24 \mathrm{~h}$ after in vitro stimulation with vmZP3. T cell proliferation was measured as rate of $\left[{ }^{3} \mathrm{H}-\right]$ thymidine uptake of the enriched CD4 ${ }^{+} \mathrm{T}$. cell population. Cell culture supernatants harvested in parallel to the proliferation assays were analysed by ELISA for levels of the cytokines interferon- $\gamma$ (IFN $\gamma$ )

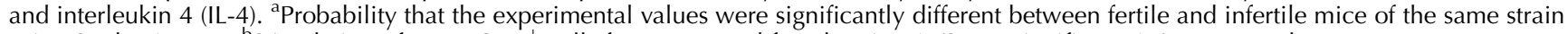
using Student's $t$-test. ${ }^{b}$ Stimulation of naïve $\mathrm{CD} 4^{+}$cells from untreated female mice; N/S, not significant; N/T, not tested; cpm, counts per minute. 
animals produced IgG antibodies that cross-reacted with the recombinant protein to which they were immunized by ELISA (Fig. 1) as well as to the heterologous antigens by ELISA and Western blot (results not shown), but no correlation between the levels of total IgG antibody and infertility was observed for either antigen in the two mouse strains. Although antibody responses varied widely between individual mice, there was also no significant difference by ELISA between fertile and infertile mice in the mean levels of IgG1 and IgG2a isotypes (Fig. 1). However, the mean levels of total $\lg G$ and $\lg \mathrm{G} 2 \mathrm{a}$ antibody were significantly higher $(P=0.01)$ in CBA compared with BALB/c mice.

\section{Ovarian pathology}

Ovaries from fertile and infertile CBA and BALB/C mice were stained with haematoxylin and eosin and examined by microscopy (Fig. 2). All infertile BALB/C mice and all but one infertile CBA mouse treated with vmZP3 (Fig. 2E,F) and one infertile BALB/C mouse treated with vpZPC
(Fig. 2I) showed altered ovarian histology compared with controls (Fig. 2A,B) and appeared similar to those described previously for ZP3 immunized mice (Jackson et al. 1998, Lloyd et al. 2003). Specifically, the ovaries lacked mature follicles and contained numerous immature follicles. The immature follicles contained oocytes surrounded by a small amount of basophilic material and a single layer of follicular epithelial cells. The ovaries of some infertile CBA mice also contained a few larger more mature follicles. These more mature follicles were almost filled with follicular epithelial cells, a small proportion of which were undergoing necrosis. There was also evidence of poorly defined corpora lutea apparently undergoing involution. In contrast, the remaining ovaries of fertile $\mathrm{BALB} / \mathrm{C}$ mice and CBA mice (fertile and infertile) immunized with vmZP3 (Fig. 2C,D) or vpZPC (Fig. 2G,H) showed no abnormalities and appeared similar to the controls. There were no inflammatory cells, or other features of inflammation such as lymphocytic infiltration, in any of
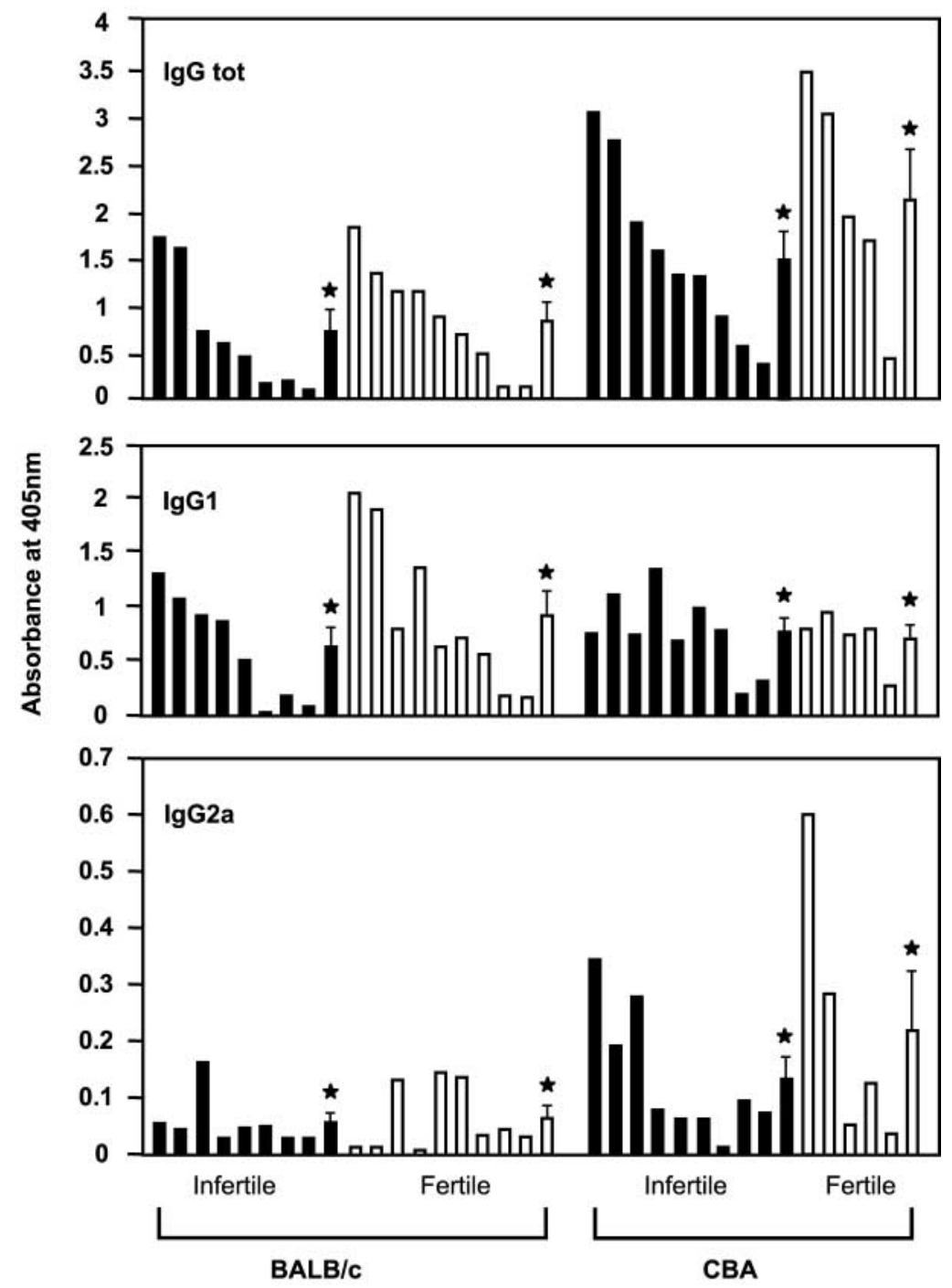

Figure 1 Serum $\lg G, \lg G 1$ and $\lg G 2 a$ antibody responses in individual female BALB/C and CBA mice immunized with recombinant vmZP3 assessed by ELISA. ELISA values are shown as absorbance readings at $405 \mathrm{~nm}$ against purified mouse ZP3 produced by recombinant myxoma virus. All sera were diluted 1:100. Infertile mice are indicated by solid bars. Means for each group are indicated by asterisks. ELISA values for pre-immune and control sera were negative (absorbance $<0.1$ ). There was a significant difference $(P<0.01)$ in total (tot) IgG and IgG2a antibody levels between BALB/C and CBA mice using a General Linear Model ANOVA. 
BALB/c
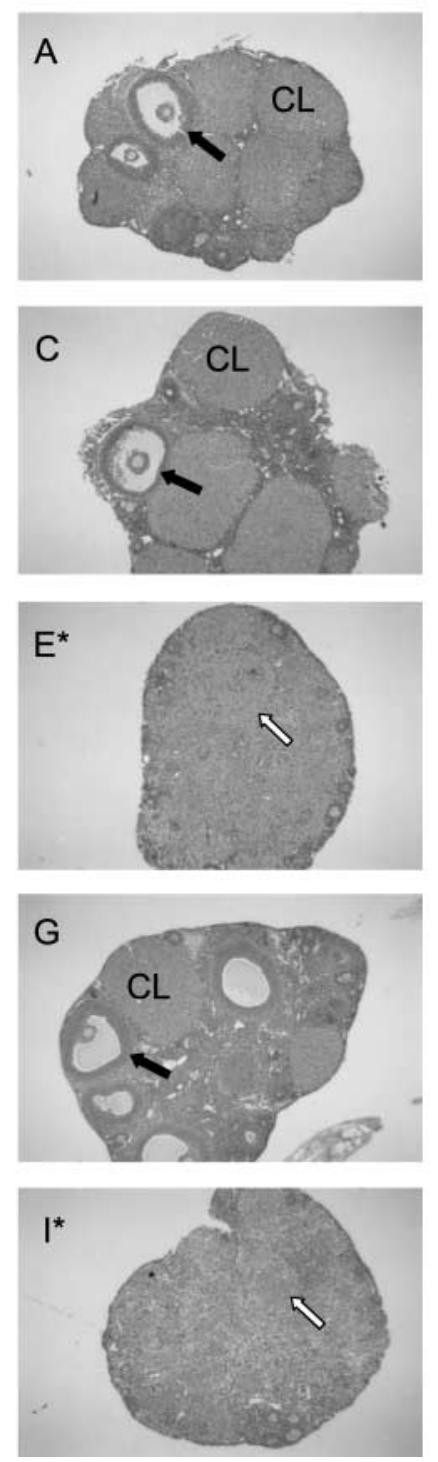

CBA
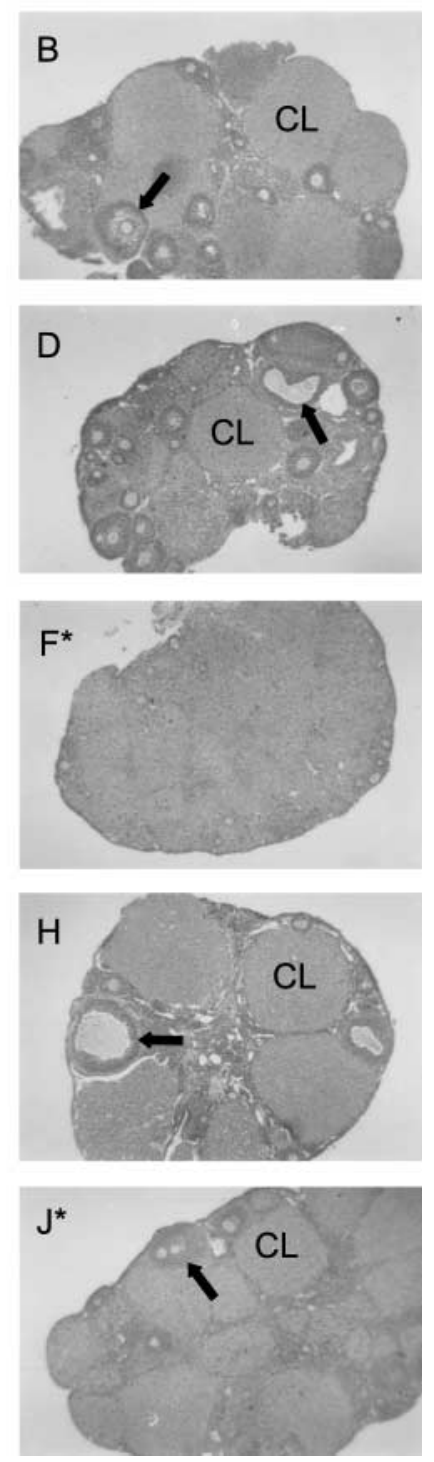

Figure 2 Haematoxylin and eosin stained sections of ovaries ( $\times 50$ magnification) collected from mice immunized with ZP antigens. Female BALB/C (A, C, E, $G, I)$ and $C B A(B, D, F, H, J)$ mice were immunized with PBS $(A, B), v m Z P 3(C-F)$ or vpZPC $(G-J)$, paired with proven fertile males and allowed to produce litters. Ovaries were collected 7 weeks $(C, E), 10$ weeks $(B, D, F, H, J)$, or 13 weeks $(A, G, I)$ after the final immunization. $\mathrm{CL}$, corpora lutea; solid arrows indicate maturing follicles; open arrows indicate involuting corpora lutea. Asterisks indicate ovaries from mice that failed to produce a litter. the ovaries upon autopsy between 3 and 4 months after the first immunizations.

\section{Discussion}

In this study we have characterised the immune responses required to induce infertility in mice immunized with recombinant zona pellucida proteins. In particular, the role of cell-mediated immunity in the induction of infertility was explored using a prime/boost protocol. The prime/boost system involves immunization with protein emulsified in Freund's complete adjuvant, followed by boosts with protein in Freund's incomplete adjuvant. This protocol has been used extensively in studies of autoimmune diseases and leads to the induction of both Th1 and Th2 immune responses (Billiau \& Matthys 2001). The fertility of $B A L B / C$ and $C B A$ strains of mice immunized with the vmZP3 protein was significantly reduced compared with controls and this enabled us to assess the relative contributions of these responses to the induction of infertility.

It appears that two different antigen-dependent mechanisms of infertility operate in response to immunization with recombinant ZP3 proteins. Ovaries of infertile mice immunized with vmZP3 lacked mature follicles whereas the ovaries from most infertile vpZPC immunized mice appeared normal. This suggests that infertility in response to vmZP3 is due to prevention of oocyte development within the ovary, whilst infertility in vpZPC immunized mice occurs later in development through prevention of fertilization or implantation of early embryos. These contrasting physiological responses to vmZP3 and vpZPC support the conclusion that complex immune responses determine how mice become infertile. 
The delayed type hypersensitivity (DTH) response is primarily regulated by $\mathrm{CD} 4^{+} \mathrm{T}$ helper Th1 cells (Mosmann \& Moore 1991, Billiau \& Matthys 2001) and so this method was used to assess the status of in vivo Th1 immune responses to the recombinant zona pellucida proteins. All $\mathrm{BALB} / \mathrm{C}$ and CBA mice immunized with vmZP3 or vpZPC induced cell-mediated responses and the DTH responses were similar between fertile and infertile mice in each strain. However, the DTH response in CBA mice to vpZPC, where no significant effect on fertility was detected, was significantly greater $(P<0.001)$ than in all the other groups. The correlation between higher DTH responses and retention of fertility in CBA mice suggests that a bias towards a Th1 response may reduce the contraceptive effect.

Analysis of the cytokine profiles of $\mathrm{CD}^{+}$cells isolated from fertile and infertile mice further support the hypothesis that a Th2- and not a Th1-like response to ZP3 antigens is required for infertility. The levels of IL-4 (a Type 2 cytokine) in the supernatants of vmZP3-stimulated CD4 ${ }^{+}$ cells from both fertile and infertile mice immunized with vmZP3 were considerably lower than in naïve mice, whereas IFN $\gamma$ (a Type 1 cytokine) levels were more comparable. These cytokine responses are consistent with earlier reports that cultured supernatants from mice immunized with a ZP3 peptide produce IFN $\gamma$ but little IL-4 in response to antigen compared with naïve mice (Lou et al. 1995b). The lower levels of IL-4 produced by vmZP3 immunized mice are likely to be due to consumption of IL-4 by vmZP3-specific T cells (Ewen \& Baca-Estrada 2001). However, supernatants of $\mathrm{CD}^{+}$cells isolated from infertile mice contained significantly more IL-4 than fertile mice in both the BALB/C and CBA strains of mice, indicating that infertility is associated with increased activity of Th2 cells. Conversely, supernatants of $\mathrm{CD}^{+}$cells isolated from fertile BALB/c mice contained significantly more IFN $\gamma$ than infertile mice, suggesting that a dominant Th1 response interferes with the block to fertility. The situation in CBA mice appears more complex as the infertile CBA mice developed significantly more IFN $\gamma$ than the fertile mice. However, this was balanced by greatly reduced levels of IL-4 in the fertile CBA mice relative to the infertile mice. The contrasting levels of IFN $\gamma$ in the infertile BALB/C and CBA mice therefore reflect mouse strain dependent inhibition by Th1 responses of Th2 cytokines such as IL-4.

Antibodies are clearly important for infertility as several studies report that high titres of ZP-specific total IgG antibodies are associated with infertility in mice immunized with ZP3 peptides or passively immunized with antibodies (East et al. 1985, Millar et al. 1989, Lou et al. 1995a, Sadler et al. 1999, Hardy et al. 2002b, Lloyd et al. 2003). However, in some cases individuals with high titres remain fertile and antibody titres do not appear to be associated with infertility in all mice immunized with recombinant ZP3 proteins (Hardy et al. 2003, Lloyd et al. 2003). We therefore explored whether the induction of particular antibody subclasses has greater contraceptive relevance than the overall IgG responses. For example, antibody subclasses such as IgG1 and IgG2a vary in their affinity and avidity for the target molecule and production of the Th1 cytokine IFN $\gamma$ can lead to the production of IgG2a whereas the Th2 cytokine IL-4 predisposes mice to produce IgG1 (Klinman 1990). However, we found no correlation between $\operatorname{lgG} 1$ or $\operatorname{lgG} 2 \mathrm{a}$ antibodies and infertility in either $\mathrm{BALB} / \mathrm{C}$ or CBA mice. CBA mice developed higher IgG2a levels than BALB/C mice, but these were not associated with elevated IFN $\gamma$ levels as expected, suggesting that the interactions between Th1 and Th2 responses, in addition to IFN $\gamma$ expression and antibody levels, determine whether ZP3-immunized mice become infertile.

Previously, it has been reported that Th1-like ZP3specific $T$ cells migrate to the ovaries and induce mononuclear cell infiltrations, but only when ZP3 specific antibodies are present (Lou et al. 2000, Lou \& Borillo 2003). However, in our study we found no evidence for inflammatory cells in the ovaries upon autopsy at around 3-4 months after the first immunization with ZP antigens. This is, however, consistent with an earlier report that mice fully recover from ZP3-induced ovarian inflammation within four months after exposure to the antigen (Lou et al. 1995b). In addition, mice injected with ZP3-specific Th1 cells develop inflammatory responses but remain fertile (Bagavant et al. 1999). In another report, increased ovarian pathology coincided with elevated levels of IL-4 and IL-5 in neonatal mice immunized with mouse ZP3 peptide, due to an underlying infection with pinworms that predisposed them to develop Th2-like responses (Agersborg et al. 2001). These results further support the conclusion that progression to infertility following immunization with ZP3 antigens relies on the development of Th2 responses in mice.

Characterisation of the immune response to ZP3 associated with induction of infertility is essential for making decisions on how best to obtain appropriate contraceptive immune responses. The induction of infertility in mice using viral vectors has previously been shown to be more efficacious than the prime/boost method (Jackson et al. 1998, Hardy et al. 2003, Lloyd et al. 2003). Previous experiments conducted with recombinant pox viruses expressing IL-4 have demonstrated that it is possible for co-expression of a Th2 cytokine to overcome Th1 biased immune anti-viral responses in genetically resistant strains of mice (Sharma et al. 1996, Jackson et al. 2001). We therefore propose that the use of Th2 immune modulating molecules should be given serious consideration in attempts to further improve the effectiveness of recombinant contraceptive vaccines.

\section{Acknowledgements}

The authors thank Kelly Debono, Jenny Swan and Juliet Fisher for technical assistance and animal husbandry. We also thank 
Peter Kerr and Suzie Collins for their technical assistance and for the use of laboratories and equipment for the T-cell proliferation experiments. The authors are grateful to Charles Krebs for statistical advice and analyses and Terry Rothwell for providing detailed histopathology reports on the ovaries. This work was supported by funds provided by the Australian Grains Research and Development Corporation (CSV16) and the Australian Government's Cooperative Research Centres Program.

\section{References}

Agersborg SS, Garza KM \& Tung KS 2001 Intestinal parasitism terminates self tolerance and enhances neonatal induction of autoimmune disease and memory. European Journal of Immunology 31 851-859.

Bagavant H, Adams S, Terranova P, Chang A, Kraemer FW, Lou Y, Kasai K, Luo AM \& Tung KS 1999 Autoimmune ovarian inflammation triggered by proinflammatory (Th1) T cells is compatible with normal ovarian function in mice. Biology of Reproduction 61 635-642.

Billiau A \& Matthys P 2001 Modes of action of Freund's adjuvants in experimental models of autoimmune diseases. Journal of Leukocyte Biology 70 849-860.

Brown RG, Bowen WD, Eddington JD, Kimmins WC, Mezei M, Parsons JL \& Pohajdak B 1997 Evidence for a long-lasting single administration contraceptive vaccine in wild grey seals. Journal of Reproductive Immunology 35 43-51.

Chambers LK, Lawson MA \& Hinds LA 1999 Biological control of rodents - the case for fertility control using immunocontraception. In Ecologically-Based Rodent Management, pp 215-242. Eds G Singleton, L Hinds, H Leirs \& Z Zhang. Canberra: Australian Centre for International Agricultural Research.

Dunbar BS, Lo C, Powell J \& Stevens VC 1989 Use of a synthetic peptide adjuvant for the immunization of baboons with denatured and deglycosylated pig zona pellucida glycoproteins. Fertility and Sterility 52311 -318.

East IJ, Gulyas BJ \& Dean J 1985 Monoclonal antibodies to the murine zona pellucida protein with sperm receptor activity: effects on fertilization and early development. Developmental Biology 109 268-273.

Ewen C \& Baca-Estrada ME 2001 Evaluation of interleukin-4 concentration by ELISA is influenced by the consumption of IL-4 by cultured cells. Journal of Interferon Cytokine Research 21 39-43.

Fitchen J, Beachy RN \& Hein MB 1995 Plant virus expressing hybrid coat protein with added murine epitope elicits autoantibody response. Vaccine 13 1051-1057.

Govind CK \& Gupta SK 2000 Failure of female baboons (Papio anubis) to conceive following immunization with recombinant non-human primate zona pellucida glycoprotein-B expressed in Escherichia coli. Vaccine 18 2970-2978.

Hardy CM, Pekin J \& ten Have J 2002a Mouse-specific immunocontraceptive polyepitope vaccines. Reproduction Supplement $\mathbf{6 0}$ 19-30.

Hardy CM, ten Have JF, Mobbs KJ \& Hinds LA 2002b Assessment of the immunocontraceptive effect of a zona pellucida 3 peptide antigen in wild mice. Reproduction Fertility and Development 14 $151-155$.

Hardy CM, ten Have JF, Pekin J, Beaton S, Jackson RJ \& Clydesdale G 2003 Contraceptive responses of mice immunized with purified recombinant mouse zona pellucida subunit 3 (mZP3) proteins. Reproduction 126 49-59.

Hasegawa A, Koyama K, Inoue M, Takemura T \& Isojima S 1992 Antifertility effect of active immunization with ZP4 glycoprotein family of porcine zona pellucida in hamsters. Journal of Reproductive Immunology 22 197-210.

Jackson RJ, Maguire DJ, Hinds LA \& Ramshaw IA 1998 Infertility in mice induced by a recombinant ectromelia virus expressing mouse zona pellucida glycoprotein 3. Biology of Reproduction $\mathbf{5 8}$ $152-159$.

Jackson RJ, Ramsay AJ, Christensen CD, Beaton S, Hall DF \& Ramshaw IA 2001 Expression of mouse interleukin-4 by a recombinant ectromelia virus suppresses cytolytic lymphocyte responses and overcomes genetic resistance to mousepox. Journal of Virology $751205-1210$.

Kerr PJ, Jackson RJ, Robinson AJ, Swan J, Silvers L, French N, Clarke H, Hall DF \& Holland MK 1999 Infertility in female rabbits (Oryctolagus cuniculus) alloimmunized with the rabbit zona pellucida protein ZPB either as a purified recombinant protein or expressed by recombinant myxoma virus. Biology of Reproduction $61606-613$.

Kirkpatrick JF, Liu IM, Turner JW Jr, Naugle R \& Keiper R 1992 Long-term effects of porcine zonae pellucidae immunocontraception on ovarian function in feral horses (Equus caballus). Journal of Reproduction and Fertility 94 437-444.

Klinman DM $1990 \operatorname{lgG} 1$ and $\operatorname{lgG} 2 \mathrm{a}$ production by autoimmune B cells treated in vitro with IL-4 and IFN-gamma. Journal of Immunology 144 2529-2534.

Lea IA, Widgren EE \& $\mathbf{O}^{\prime}$ Rand MG 2002 Analysis of recombinant mouse zona pellucida protein 2 (ZP2) constructs for immunocontraception. Vaccine $201515-1523$.

Li D, Sun X, Li C, Cai L \& Meng Y 2002 Effects on fertility of immunizing mice with anti-idiotypic antibodies to porcine zona pellucida antigen. Journal of Reproductive Immunology 54 81-92.

Lloyd ML, Shellam GR, Papadimitriou JM \& Lawson MA 2003 Immunocontraception is induced in BALB/c mice inoculated with murine cytomegalovirus expressing mouse zona pellucida 3. Biology of Reproduction 68 2024-2032.

Lou YH \& Borillo J 2003 Migration of T cells from nearby inflammatory foci into antibody bound tissue: a relay of T cell and antibody actions in targeting native autoantigen. Journal of Autoimmunity $2127-35$.

Lou Y, Ang J, Thai H, McElveen F \& Tung KS 1995a A zona pellucida 3 peptide vaccine induces antibodies and reversible infertility without ovarian pathology. Journal of Immunology $\mathbf{1 5 5}$ 2715-2720.

Lou YH, McElveen F, Adams S \& Tung KS 1995b Altered target organ. A mechanism of postrecovery resistance to murine autoimmune oophoritis. Journal of Immunology 155 3667-3673.

Lou YH, Park KK, Agersborg S, Alard P \& Tung KS 2000 Retargeting T cell-mediated inflammation: a new perspective on autoantibody action. Journal of Immunology $1645251-5257$.

Mahi-Brown CA, Yanagimachi R, Hoffman JC \& Huang TT Jr 1985 Fertility control in the bitch by active immunization with porcine zonae pellucidae: use of different adjuvants and patterns of estradiol and progesterone levels in estrous cycles. Biology of Reproduction 32 761-772.

Martinez ML \& Harris JD 2000 Effectiveness of zona pellucida protein ZPB as an immunocontraceptive antigen. Journal of Reproduction and Fertility 120 19-32.

Millar SE, Chamow SM, Baur AW, Oliver C, Robey F \& Dean J 1989 Vaccination with a synthetic zona pellucida peptide produces long-term contraception in female mice. Science 246 935-938.

Miller LA, Johns BE, Elias DJ \& Killian GJ 1999a Oral vaccination of white-tailed deer using a recombinant Bacillus Calmette-Guerin vaccine expressing the Borrelia burgdorferi outer surface protein A: prospects for immunocontraception. American Journal of Reproductive Immunology 41 279-285.

Miller LA, Johns BE \& Killian GJ 1999b Long-term effects of PZP immunization on reproduction in white-tailed deer. Vaccine $\mathbf{1 8}$ $568-574$

Mosmann TR \& Moore KW 1991 The role of IL-10 in crossregulation of TH1 and TH2 responses. Immunology Today 12 A49-A53.

Prasad SV, Wilkins B \& Dunbar BS 1996 Molecular biology approaches to evaluate species variation in immunogenicity and antigenicity of zona pellucida proteins. Journal of Reproduction and Fertility Supplement 50 143-149. 
Ramsay AJ \& Ramshaw IA 1997 Cytokine enhancement of immune responses important for immunocontraception. Reproduction, Fertility and Development 9 91-97.

Rhim SH, Millar SE, Robey F, Luo AM, Lou YH, Yule T, Allen P, Dean J \& Tung KS 1992 Autoimmune disease of the ovary induced by a ZP3 peptide from the mouse zona pellucida. Journal of Clinical Investigation 89 28-35.

Sacco AG, Subramanian MG \& Yurewicz EC 1981 Active immunization of mice with porcine zonae pellucidae: immune response and effect on fertility. Journal of Experimental Zoology 218 405-418.

Sacco AG, Pierce DL, Subramanian MG, Yurewicz EC \& Dukelow WR 1987 Ovaries remain functional in squirrel monkeys (Saimiri sciureus) immunized with porcine zona pellucida 55000 macromolecule. Biology of Reproduction 36 481-490.

Sacco AG, Yurewicz EC \& Subramanian MG 1989 Effect of varying dosages and adjuvants on antibody response in squirrel monkeys (Saimiri sciureus) immunized with the porcine zona pellucida $M_{\mathrm{r}}=55000$ glycoprotein (ZP3). American Journal of Reproductive Immunology $\mathbf{2 1} 1-8$.

Sadler K, Bird PH, Brown LE \& Jackson DC 1999 The antigenic and immunogenic properties of synthetic peptide immunocontraceptive vaccine candidates based on gamete antigens. Vaccine $\mathbf{1 8}$ 416-425.

Schwoebel ED, Vandevoort CA, Lee VH, Lo YK \& Dunbar BS 1992 Molecular analysis of the antigenicity and immunogenicity of recombinant zona pellucida antigens in a primate model. Biology of Reproduction 47 857-865.
Sharma DP, Ramsay AJ, Maguire DJ, Rolph MS \& Ramshaw IA 1996 Interleukin-4 mediates down regulation of antiviral cytokine expression and cytotoxic T-lymphocyte responses and exacerbates vaccinia virus infection in vivo. Journal of Virology $\mathbf{7 0}$ $7103-7107$.

Srivastava N, Santhanam R, Sheela P, Mukund S, Thakral SS, Malik BS \& Gupta SK 2002 Evaluation of the immunocontraceptive potential of Escherichia coli-expressed recombinant dog ZP2 and ZP3 in a homologous animal model. Reproduction $\mathbf{1 2 3}$ $847-857$.

VandeVoort CA, Schwoebel ED \& Dunbar BS 1995 Immunization of monkeys with recombinant complimentary deoxyribonucleic acid expressed zona pellucida proteins. Fertility and Sterility $\mathbf{6 4}$ 838-847.

Wyatt LS, Moss B \& Rozenblatt S 1995 Replication-deficient vaccinia virus encoding bacteriophage T7 RNA polymerase for transient gene expression in mammalian cells. Virology 210 202-205.

Zhang X, Lou YH, Koopman M, Doggett T, Tung KS \& Curtiss R 3rd 1997 Antibody responses and infertility in mice following oral immunization with attenuated Salmonella typhimurium expressing recombinant murine ZP3 [published erratum appears in Biology of Reproduction 199756 1069]. Biology of Reproduction 56 33-41.

Received 11 May 2004

First decision 16 July 2004

Accepted 20 August 2004 